\title{
Activation is not a panacea: active labour market policy, long-term unemployment and institutional complementarity
}

\author{
LUC BENDA*, FERRY KOSTER ${ }^{* *}$ AND ROMKE VAN DER VEEN*** \\ *Department of Public Administration and Sociology, Faculty of Social Sciences, Erasmus \\ University Rotterdam, Burgemeester Oudlaan 50, 3062 PA, Rotterdam, The Netherlands \\ email: benda@essb.eur.nl \\ ** Department of Public Administration and Sociology, Faculty of Social Sciences, Erasmus \\ University Rotterdam, Burgemeester Oudlaan 50, 3062 PA, Rotterdam, The Netherlands \\ email: koster@essb.eur.nl \\ *** Department of Public Administration and Sociology, Faculty of Social Sciences, Erasmus \\ University Rotterdam, Burgemeester Oudlaan 50, 3062 PA, Rotterdam, The Netherlands \\ email: vanderveen@essb.eur.nl
}

\begin{abstract}
Evaluation studies of active labour market policy show different activation measures generate contradictory results. In the present study, we argue that these contradictory results are due to the fact that the outcomes of activation measures depend on other institutions. The outcome measure in this study is the long-term unemployment rate. Two labour market institutions are of special interest in this context: namely, employment protection and unemployment benefits. Both institutions, depending on their design, may either increase or decrease the effectiveness of active labour market policies in lowering long-term unemployment. Based on an analysis of macro-level data on 20 countries over a period of 16 years, our results show that employment protection strictness and unemployment benefit generosity interact with the way in which active labour market policies relate to long-term unemployment. Our results also indicate that, depending on the measure used, active labour market policies fit either in a flexible or in a coordinated labour market. This suggests that active labour market policies can adhere to both institutional logics, which are encapsulated in different types of measures.
\end{abstract}

Keywords: institutional complementarity; active labour market policy; long-term unemployment; employment protection legislation; unemployment benefits

\section{Introduction}

Since the nineties, many European welfare states started to transform into social investment states as a reaction to the changing risks due to the emergence of the post-industrial society (Van Kersbergen and Hemerijck, 2012). Within this form of welfare state, active labour market policies (ALMPs) play a dominant role to create a more socially inclusive and economically productive labour market (Morel et al., 2012). ALMPs are social policy measures that stimulate labour market participation through human capital investments and job search 
assistance. But activation can also be accomplished with benefits conditionality, sanctions and policies that have a strong emphasis on work (Crouch and Keune, 2012, p. 57). Examples of ALMPs are training programmes, hiring subsidies or public employment programmes. As labour market participation is increasingly becoming a condition for one's personal and social welfare (Bonoli, 2005), reducing and preventing long-term unemployment belong to the central pillars of ALMPs. However, the evaluation literature on the effects of ALMP is ambiguous in its conclusions. Contradicting results on the effects of ALMP on labour market outcomes are reported (see, for instance, Calmfors et al., 2001; Martin and Grubb, 2001; Martin, 2015). Although this strand of literature typically emphasises the level of analysis (macro vs. micro) or the type of ALMP used, we argue that other labour market institutions also play a role in the observed effect heterogeneity of ALMPs. Most theories related to ALMP - such as human capital theory, search theory and statistical discrimination theory - often depart from an economic rational choice perspective. These theories do not emphasise the influence other institutions have on the effectiveness of ALMPs. Hence, this study aims to provide additional insights by studying potential institutional complementarities that exist between ALMPs and the institutional structure they are embedded in.

Institutions are social structures that "comprise regulative, normative and cultural-cognitive elements that, together with associated activities and resources, provide stability and meaning to social life" (Scott, 2014, p. 56). The idea that institutions are complementary to other institutions plays a fundamental role in the theoretical ideas on economic and labour market models, such as Varieties of Capitalism (Hall and Soskice, 2001) or flexicurity (Madsen, 2004). These scholars argue that certain institutions or specific configurations of these institutions produce optimal results. The effects of the individual institutions are optimised through the interaction with other institutions. These interactions between different institutions enhance economic productivity and competitiveness. This implies that institutional practices should not be randomly distributed and organised across different economic spheres (Hall and Soskice, 2001, pp. 17-20). Thus, institutional complementarity runs against the idea of 'one best way' but also against the idea that any combination of institutions will effectively work together (Amable, 2016). Empirical research shows that labour market institutions do not only affect the labour market directly but also interact with other institutions related to labour market outcomes (Blanchard and Tirole, 2004; Eichhorst and Konle-Seidl, 2006). Thus, reasoned from the notion of institutional complementarity, the efficiency and effectiveness of ALMP are also influenced by other institutions and their specific configuration.

In this study, a focus is put on the potential complementarity of ALMPs with unemployment benefits (UBs) and employment protection legislation (EPL) for two reasons. First, in most European countries UBs and EPL were 
already in place before ALMP were implemented on a larger scale at the national level. ALMPs are therefore more embedded in these institutions instead of vice versa. Furthermore, both institutions affect both sides of the labour market. As most ALMP studies focus on the supply side, they paint an incomplete picture. Treating the demand side as a given underplays the role employers play in the emergence of ALMP effects (Ingold and Stuart, 2015). Several studies show that national characteristics indeed play a role in the likelihood that employers engage in ALMPs (Martin, 2004; Martin and Swank, 2004; Swank and Martin, 2001). Therefore, by also theorising and analysing the potential influence of the demand side in ALMP effectiveness, next to the supply side, we try to provide a more complete, although not exhaustive, picture of how potential institutional complementarities between ALMP and its institutional context come to be.

The research question in this article is: How is the relationship between active labour market policies and long-term unemployment affected by employment protection legislation strictness and unemployment benefit generosity? Panel data from 20 European countries during 1996 and 2012 were used to study the potential complementarities in relation the long-term unemployment. As ALMP began to play a larger role in the social policy mix in most European countries during the mid-nineties, 1996 is a logical starting point for the analysis.

This article is structured as follows: in the next section we discuss the theoretical underpinnings of ALMP, EPL and UBs in their relation to long-term unemployment. Accordingly, we formulate our hypotheses. Then, we describe our methodology and present our results. We conclude by answering our research question and discuss the findings presented in this article.

\section{ALMP and long-term unemployment}

According to the program theory of ALMP, three factors play an important role in how ALMPs influence the long-term unemployment rate. First, ALMPs try to alter the perception employers have on the (long-term) unemployed related to decisions during recruitment and selection processes. This alteration of perception can be accomplished in two ways: namely, by appealing to the economic self-interest of employers and by reducing the information asymmetry employers have on the productive capabilities of the applicant. Hiring decisions have a high level of financial uncertainty for employers due to information asymmetry. Hence, employers use unemployment duration, among other things, as a screening tool when making recruitment decisions (Eriksson and Rooth, 2014). Longterm unemployment is often associated with the deterioration of skills and the development of undesirable behavioural traits, i.e. de-socialisation for work (Blanchard, 1991). Thus, employers perceive the long-term unemployed as a bigger financial risk compared to those with no or a shorter unemployment period. ALMPs try to alter that risk assessment by providing financial incentives that reduce the financial risk employers have when they hire a long-term 
unemployed individual (Brown and Koettl, 2015). Examples of such measures are hiring or wage subsidies.

Another way to alter the perception of employers and increase demand is by reducing the information asymmetry employers have on the abilities of the applicant (ibid.) ALMPs try to reduce the stigma that rests upon long-term unemployment and influence the risk assessment employers make. For instance, an employer has the opportunity to obtain information about the long-term unemployed individual through subsidised employment without financial risk. In turn, long-term unemployed individuals have a chance to show their value to the employer. However, ALMPs can also enforce the stigma when programmes are too narrowly targeted at high-risk groups. If people participate in these programmes, employers can interpret that as a signal for low productivity and may therefore decide not to hire such a person (Burtless, 1985). As a result, the labour market opportunities of these participants are reduced and these programmes increase long-term unemployment.

Second, ALMPs also aim to influence the long-term unemployment rate through human capital enhancement. This improves the labour market position of the (long-term) unemployed, which increases the probability of obtaining employment. These activation programmes are designed to assist the (longterm) unemployed by upgrading their human capital. This upgrading should contribute to a higher probability of finding not only a new job but also one of higher quality that leads to a sustainable reintegration into the labour market. Furthermore, they also serve the purpose to increase successful matchmaking in sectors that are in need of employees with specific skills. This improvement in matchmaking should then lead to a lower inflow to unemployment and as a result in a lower long-term unemployment rate (Boone and van Ours, 2004).

Third, ALMPs also try to influence the search behaviour of the unemployed by appealing to the economic self-interest of the unemployed with the intent to reduce the probability of becoming long-term unemployed. This happens in multiple ways. The most obvious manner is through job search assistance by councillors of public employment services. They aim to support the unemployed by providing information on job openings or by controlling their job search efforts (Brown and Koettl, 2015). Moreover, it is argued that ALMPs also might influence job search behaviour in other ways. A change in job search behaviour can occur prior to mandatory participation in an ALMP programme. The likelihood increases that an individual leaves unemployment before the beginning of the programme, because of the occurrence of the so-called motivation effect. This effect manifests itself when participating in activation programmes is perceived as less attractive than having a job. The prospect of mandatory participation is perceived as negative, which in turn increases job search intensity (Madsen, 2004). When job search activities are not effective or are purposely of low quality, mandatory programmes can be used to change job search 
behaviour. However, ALMP participation can also prolong the unemployment duration as it potentially decreases the job search intensity as well. This is also referred to as the lock-in effect. When people are participating in all sorts of activation programmes, they put less effort into job search activities. Thus the unemployment spell is prolonged and the long-term unemployment rate increases (ibid.). Van Ours (2004) finds that the occurrence of a lock-in effect is dependent on the time a job seeker participates in a programme. More specifically, he argues that short-term subsided jobs heighten the likelihood that a job seeker finds a regular job. But when the duration increases the positive effect of subsidised jobs decreases as lock-in effects occur.

\section{Linking activation to employment protection strictness and unemployment benefit generosity}

In this section, we will theorise how UBs and EPL might affect the relationship between ALMP and long-term unemployment. Only hypotheses are formulated on the moderation effects of UBs and EPL on ALMP and long-term unemployment. The reason for doing so is that, according to the idea of institutional complementarity, institutional effects are influenced by other institutions. Thus, the main effects are not of primary concern but the moderated effects are.

\section{Employment protection strictness}

It is argued that EPL affects the risk assessment employers make during recruitment and selection processes. EPL directly influences the firing costs associated with dismissal through measures such as mandated severance pay and indirectly via procedural costs. Thus, strict EPL makes it harder and more costly to fire employees. But EPL also influences the hiring of new employees indirectly. Due to economic uncertainty, employers are less likely to hire new employees to avoid high firing costs in the future (Avdagic, 2015). As hiring is less risky in labour markets with low levels of employment protection, it is expected that the potential stigma that is associated with ALMP participation is less of a concern. Because it is relatively cheap and easy to fire employees in labour markets with less strict EPL, ALMP participants might get the benefit of the doubt sooner than in labour markets with strict EPL. Furthermore, the direct effect of ALMPs on long-term unemployment is also dependent on labour demand. If employers are more hesitant to hire new employees as a result of strict EPL, then, on an aggregate level, labour demand should be lower. Because of low labour demand, it is harder to find a job, even for highly skilled job seekers (de Beer and Schils, 2009). Hence, the probability of obtaining employment diminishes, even if one portrays intense job search behaviour and has sufficient human capital because there are too few vacancies the long-term unemployed can be activated in. 
Furthermore, it is also argued that EPL influences which type of human capital is primarily developed. Two types can be distinguished: namely, specific human capital and general human capital. The latter refers to human capital that holds value to multiple employers, while the first refers to human capital that only has value for one specific employer (Becker, 1962). For people who possess high amounts of specific human capital and low amounts of general human capital, it is harder to obtain new employment compared to people with the opposite human capital composition. The composition of one's human capital is argued to be influenced by the level of employment protection strictness. As it is relatively easy to be fired in a labour market with less strict EPL, it is important to have higher amounts of general human capital to be able to easily switch between employers. Alternatively, in labour markets with strict EPL, it is in the employer's interest to invest in employees as it is more difficult to fire them. Moreover, it is also less risky for the employee to invest in firm-specific skills as they are more protected against arbitrary dismissal (Hall and Soskice, 2001). Thus, the probability is higher that the long-term unemployed in flexible labour markets have more general skills and need fewer human capital investments to be able to find a job compared to the long-term unemployed in labour markets with strict EPL. In other words, with the same amount of human capital advancement, the probability is higher that a long-term unemployed individual obtains employment in a labour market with less strict EPL than in a labour market with strict EPL.

To summarise, it can be argued that stricter EPL decreases the ALMPeffectiveness concerning the reduction of long-term unemployment and may even induce a positive relationship between ALMP and long-term unemployment. Stricter EPL reinforces the consequences of stigmatisation through ALMP programme participation and lowers labour demand. Both effects make the transition into employment harder. Additionally, less general human capital tends to be present in this type of labour market, implying that more activation resources are needed to obtain employment. Thus, we hypothesise that the relation between ALMP effort and long-term unemployment is positively moderated by EPL strictness $\left(\mathrm{H}_{1}\right)$.

However, the opposite is also possible. It is also argued that more negative selection takes place during the hiring and firing of employees in labour markets with less strict EPL. Individuals with a weaker labour market position have a much higher chance of being fired, as it is relatively cheap to dispose of unwanted employees. At the same time, chances to reintegrate into the labour market are lower: for example, because these employees lack the right skill set or belong to a discriminated minority. These negative selection processes are supposed to happen more in labour markets with less strict EPL than those with strict EPL because more people are hired and fired within the same time frame (Madsen, 2004). This implies that the composition of the long-term unemployed 
differs between both types of labour markets. Labour markets with less strict EPL should contain more unemployed who have a greater distance from the labour market than those with strict EPL. This potentially also affects the effectiveness of ALMP. As employment histories are used as signals during recruitment and selection processes, very inconsistent employment histories signal a higher risk to the hiring employer. Moreover, these turbulent labour market experiences might also result in discouragement and decreased job search activities, as the benefits do not outweigh the costs. This implies that the ALMP clientele of both types of labour markets differs on average. Consequently, activation programmes in labour markets with less strict EPL potentially deal on average with individuals with a greater distance from the labour market than activation programmes in labour markets with strict EPL. Fewer activation resources are needed in labour markets with strict EPL because the average ALMP participant has less distance to the labour market. We hypothesise that the relation between ALMP effort and long-term unemployment is negatively moderated by EPL strictness $\left(\mathrm{H}_{2}\right)$.

\section{Unemployment benefit generosity}

The effects of UBs on long-term unemployment are heavily debated in welfare state literature. On the one hand, scholars state that generous welfare systems provide economic protection against poverty. These arrangements protect people against poverty and its negative consequences on job search outcomes. Due to financial support, the long-term unemployed are better able to improve their skills and the quality of their job search (den Broeder, 1996, p. 12). The long-term unemployed do not suffer from stress related to poverty and are therefore better capable of improving and sustaining the quality of their job search efforts. Research shows that poverty drastically reduces the chance of (re-)employment (Caminada et al., 2012). This implies that ALMP participants in labour markets with generous UB schemes are better able to fully participate in activation programmes than those in labour markets with less generous UB schemes. This should result in higher quality human capital development due to lower levels of stress induced by the threat of the negative consequences of income loss. Furthermore, their increased search behaviour intensity, due to activation measures, should also lead to more sustainable labour market integration. As income is provided for, they are better able to find a suitable job that matches their work history and skill level instead of taking any job to prevent the negative consequences of loss of income. This suggests that future unemployment is less likely to occur.

Moreover, it is also argued that generous UBs decrease long-term unemployment as it upholds labour demand and thereby improves unemployment outflow. Upholding labour demand is facilitated through the economic stabilisation of consumer demand. When people lose their income, the economy is 
negatively affected as consumer demand decreases. In this way, labour demand decreases as well because fewer workers are needed to meet consumer demand. By providing income for those who are not able to acquire income through the labour market, consumer demand is stabilized (Hemerijck, 2012). This implies that labour markets with more generous UBs are less volatile than their counterparts. This reduces the economic uncertainty for employers and, thus, makes them more likely to hire workers, as their economic future is less uncertain. Through economic stabilisation, labour demand is upheld, which increases a higher probability of obtaining employment with the same level of job search intensity or amount of human capital.

To summarise, more UB generosity increases the effectiveness of ALMPs in reducing long-term unemployment. By providing protection against poverty, generous UBs may improve the matchmaking between ALMP participants and potential employers. Additionally, UBs also contribute to economic stability, which increases employment opportunities for ALMP participants. Hence, we hypothesise that, through income security and economic stabilisation, the relation between ALMP effort and long-term unemployment is negatively moderated by $U B$ generosity $\left(\mathrm{H}_{3}\right)$.

On the other hand, scholars argue that by providing income security a financial disincentive is given to the unemployed to obtain employment. Generous UBs tend to artificially raise and increase the reservation wage. The reservation wage is the minimum wage rate at which an unemployed individual is willing to accept a job. Therefore, when the reservation wage increases, the likelihood of finding employment decreases as well (Feldstein and Poterba, 1984). As a result, the probability of becoming long-term unemployed increases too. Furthermore, the financial disincentive also influences the level of job search intensity. Empirical research shows that unemployment benefits recipients have less contact with employers, and spend fewer monthly hours and money on job search activities compared to non-recipients (Pedersen and Smith, 2002), and also shows that job search activities tend to increase during the last period of the duration of benefit receipt (Krueger and Mueller, 2010). This implies that the unemployed start to search more actively for employment when they perceive potential economic hardship in the near future. Thus, through an increased reservation wage and reduced need to find income through labour market participation, the intended effects of ALMP are countered. The need for ALMP participants to obtain employment is reduced, which leads to lower job search intensity compared to participants in a labour market with less generous UB. ALMP participation is more likely to lead to a lock-in effect, which increases the probability of long-term unemployment when $\mathrm{UB}$ generosity is high. Our hypothesis is that the relation between ALMP effort and long-term unemployment is positively moderated by UB generosity $\left(\mathrm{H}_{4}\right)$. 


\section{Data and methods \\ Data}

For this study, we partly used the European Labour Market Resilience (ELMaR) dataset ${ }^{1}$, which is a publicly available dataset that contains crossnational and longitudinal (1996-2012) data originating from several data sources: namely, the OECD, Eurostat, the Data Base on Institutional Characteristics of Trade Unions, Wage Setting, State Intervention and Social Pacts (ICTWSS) and the Comparative Welfare Entitlements Data Set. ELMaR covers 30 European countries and 540 observations (Bigos et al., 2013). We added data to this dataset from the OECD database. We selected cases with complete information about all the variables used for the analysis. After this selection, the dataset used for the analysis contained 239 observations from 20 countries.

\section{Dependent variable}

The dependent variable in our model is long-term unemployment. We looked at the share of the total labour force who are long-term unemployed. The labour force consists of the total of employed and unemployed persons. A large share of long-term unemployment in the total labour force implies both lower inclusiveness and lower economic competitiveness and productivity. However, a large share of long-term unemployment in total unemployment does not necessarily imply low inclusiveness and low economic competitiveness and productivity. If the total unemployment is very low, but the percentage of longterm unemployment in the total unemployment is high, this still would be considered an inclusive and competitive labour market. Hence, we measured longterm unemployment as the percentage of unemployed persons of the total labour force who have been out of a job longer than a year. The data we used originates from Eurostat (for a full explanation see Eurostat, 2015). To correct for a skewed distribution, we log-transformed this variable.

\section{Independent variables}

Standard procedure in comparative social policy research is to use public spending, usually expressed as a percentage of GDP, to measure policy intensity. Gilbert (2009) argues that this measure is difficult to interpret because it neglects population size, wealth and is not corrected for need. To accommodate these critiques, ALMP effort is therefore expressed as the product of ALMP spending as the percentage of GDP and level of GDP per capita in purchasing power parities (PPPs) and constant prices (2005). This corrects the spending measure for population size and wealth of a country. This product was then divided by the unemployment rate to correct the measure for the level of need. Furthermore, Clasen et al. (2016) argue that it is imperative to differentiate between the specific programmes in ALMP because they might have differential effects. We 
differentiated ALMP into three distinct groups: namely, public employment services and administration (ALMP pes), training programmes (ALMP training), and employment programmes consisting of employment incentives, sheltered and supported employment and rehabilitation, and direct job creation (ALMP employment).

To measure employment protection strictness, the EPL-indicators of the OECD were used. Two indicators were used, one to measure employment protection strictness regarding regular contracts and one to measure employment protection strictness regarding temporary employment. Several versions exist of the EPL indicator. We used the first version of this indicator because it contains data from a longer time period. The indicator on regular EPL is based on 8 items concerning regulations for individual dismissals, including notification procedures, possibilities of delay before the notice can start, the length of notice periods, severance payments, definitions of justified or unfair dismissal, the length of the trial period, the compensation following unfair dismissal, and the possibilities of reinstatement after unfair dismissal. The temporary EPL indicator of the OECD is based on 6 items that provide information on valid cases for using fixed-term contracts, the maximum number and maximum cumulated duration of successive fixed term-contracts, types of work that are legal for temporary work agency (TWA) employment, the restrictions on the number of TWA assignments and the maximum cumulated duration of TWA assignments (for full detail, see OECD, 2015b).

Unemployment benefit generosity is operationalised using the net replacement rates as devised by Scruggs et al. (2014). The replacement rate covers only the national insurance provisions earned without income testing and it excludes additional provisions under a collective bargaining contract. Scruggs calculates the net replacement rate for "a fictive average worker in the manufacturing sector who is 40 years old, has been working for the 20 years preceding the loss of income or the benefit period" (ibid, p.8). Scruggs takes account of two household types: namely, a single and family household. The single household type refers to a person who has an average earning level, is living alone and has no children or other dependents. The family household refers to a person with an average earning level and lives together with a dependent spouse with no income. This couple has two children aged 7 and 12. We calculated the average of the two household types to provide a more general indication for the level of UB generosity of a given labour market. We lagged all the independent variables with one year, as it takes a year to become long-term unemployed.

\section{Control variables}

In this study, we control for two types of economic conditions: namely, economic growth and GDP per capita. Economic growth is included in the analysis, because during times of economic downturn the long-term unemployment rate 
increases. But at the same time governments tend to adjust their policy to dampen the effects of the economic downturn. Economic growth is measured as the percentage change in GDP per head of the population. Because we want to make a comparison across time, we used data in constant prices (2005). This is more appropriate, as this also controls for relative prices over time in addition to those across countries (OECD, 2015a). We also controlled for the level of GDP per capita as this might be correlated with the policies used and the long-term unemployment rate. In wealthy countries, the risk of long-term unemployment is lower (see Figure 1 on page 13). At the same time, countries with high GDP per capita (for instance, the Nordic countries) spend more on ALMP. GDP per capita is expressed in PPPs and in constant prices (2005), which allows for within- and between-country comparisons.

Moreover, we also controlled for demographic influences as they may also be correlated with both the policies and long-term unemployment. The age structure of a country may also confound with the relationship between social policy and long-term unemployment. Older aged people have a higher chance of becoming long-term unemployed due to age discrimination but at the same time activation policies are targeted at specific groups, such as older workers (Taylor and Walker, 1994). We controlled for the ratio of older aged people living in a country using the old age dependency ratio. The ratio is measured as the total number of people who are of an age that is higher than the working age (65 and over) compared to the total number people of working age (from 15 to 64$)$.

Another demographic factor that potentially confounds with the relationship between ALMP and long-term unemployment is labour migration. For the long-term unemployed, migration may seem like a viable option in procuring employment. When large numbers of long-term unemployed people immigrate to another country, the long-term unemployment rate reduces as well. When migration is not taken into account, the false conclusion may arise that certain types of policy are responsible for the reduction of long-term unemployment. For instance, the Baltic states are characterised by low levels of social protection but at the same time high levels of migration during the financial crisis due to deteriorating social and economic circumstances (Sippola, 2013). Migration is measured using the crude net migration rate. The Crude Net Migration rate is the ratio of the difference between the total change of the population and the natural change of the population compared to the average population in the period of one year per 1000 inhabitants.

Furthermore, we also control for characteristics of the industrial relations system. Due to the influence the social partners have on the formation of social policies (Gordon, 2015; Martin, 2004), we included union density and how collective wage setting is coordinated to control for possible confounding. Union density was measured as the ratio of wage and salary earners who 
TABLE 1: Descriptive statistics $(\mathrm{N}=239)$

\begin{tabular}{|c|c|c|c|c|}
\hline & Mean & St. Dev. & Min & Max \\
\hline Regular EPL & 2.431 & 0.728 & 1.032 & 4.583 \\
\hline Temporary EPL & 1.676 & 0.974 & 0.250 & 4.625 \\
\hline UB generosity & 0.614 & 0.143 & 0.258 & 0.825 \\
\hline Overall ALMP & 43.096 & 38.110 & 1.345 & 208.933 \\
\hline ALMP pes & 10.413 & 10.583 & 0.183 & 64.841 \\
\hline ALMP employment & 19.842 & 21.128 & 0.232 & 129.683 \\
\hline ALMP training & 12.836 & 12.869 & 0.000 & 57.951 \\
\hline Economic growth & 1.763 & 3.017 & -14.564 & 10.563 \\
\hline GDP per capita $(/ 10000)$ & 2.931 & 0.797 & 1.039 & 4.914 \\
\hline Old age dependency ratio & 22.989 & 3.460 & 15.800 & 31.400 \\
\hline Crude net migration rate & 3.145 & 3.534 & -7.500 & 15.700 \\
\hline Union density & 35.491 & 21.492 & 7.548 & 82.329 \\
\hline \multicolumn{5}{|l|}{ Coordination of wage setting } \\
\hline Fragmented wage bargaining & 0.142 & & & \\
\hline $\begin{array}{l}\text { Mixed industry and firm-level } \\
\text { bargaining }\end{array}$ & 0.230 & & & \\
\hline $\begin{array}{l}\text { Negotiation guidelines based on } \\
\text { centralized bargaining }\end{array}$ & 0.105 & & & \\
\hline $\begin{array}{l}\text { Wage norms based on centralized } \\
\text { bargaining }\end{array}$ & 0.372 & & & \\
\hline $\begin{array}{l}\text { Maximum/minimum wage rates } \\
\text { increases centralized bargaining }\end{array}$ & 0.151 & & & \\
\hline
\end{tabular}

are trade union members, divided by the total number of wage and salary earners. Five categories were included to denote the coordination of wage setting: namely (1) fragmented wage bargaining, confined largely to individual firms or plants (2) mixed industry and firm-level bargaining, weak government coordination through minimum wage setting or wage indexation (3) negotiation guidelines based on centralized bargaining (4) wage norms based on centralized bargaining by peak associations with or without government involvement and (5) maximum or minimum wage rates or increases based on centralized bargaining. We also lagged the control variables with one year; with the exception of economic growth, which is lagged with 2 years. In Table 1 the descriptive statistics of the variables used for the regression analysis are presented ${ }^{2}$.

\section{Methods and analysis}

The hierarchical structure of our data, with time nested in countries, leads to biased estimates if not corrected for due to correlated errors. A fixed effects model can be used to analyse clustered data because it corrects the error structure and also controls for time-consistent unobserved heterogeneity (Allison, 2009). The data were analysed using the plm-package in $\mathrm{R}$, which transforms the variables to deviations from the country-specific means to 


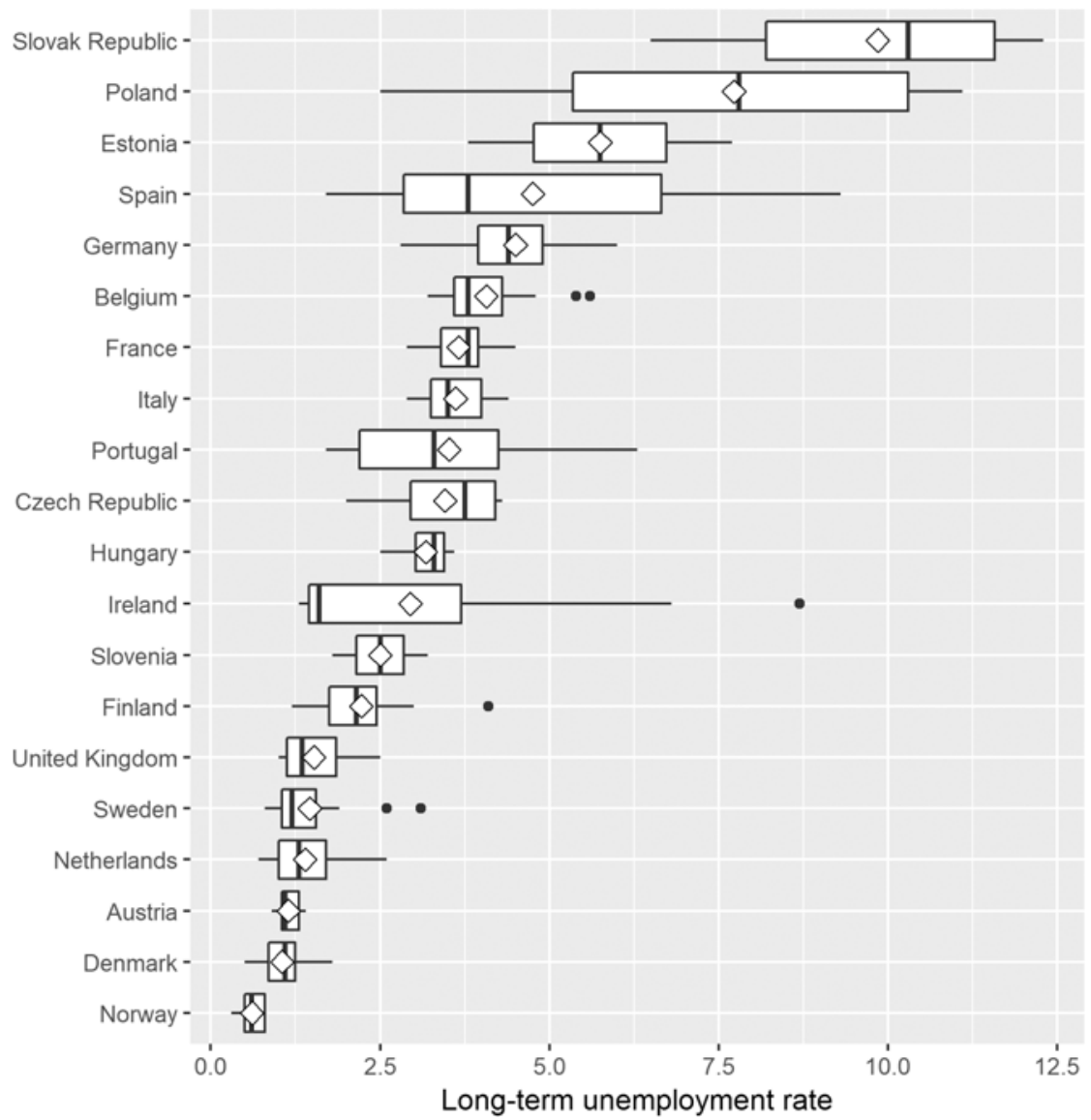

Figure 1. Long-term unemployment rate between 1997 and 2012

address the error structure and time-constant unobserved heterogeneity. Additionally, to check the robustness of the results, we also excluded one country at a time and re-estimated the models to investigate the influence of potential outliers due to the non-random nature of the sample.

\section{Results}

\section{Descriptive statistics}

Figure 1 shows the boxplot of the long-term unemployment rate differentiated by country. The white boxes depict the range between 25 percentile and 75 percentile of the data (interquartile range - IQR); thus the longer the white box is, the more volatile the long-term unemployment rate of a country is. The vertical lines in the white boxes depict the median ( 50 percentile), and the 
horizontal lines reach to the furthest data point within 1.5 times the IQR. Scores that exceed this range are displayed as a black dot. The diamond shapes depict the mean score of a country. Countries with high variances in their long-term unemployment rates are Poland, Spain and Ireland. This means that these countries have a highly volatile long-term unemployment rate. The Slovak Republic has the highest mean long-term unemployment rate and Norway the lowest.

\section{Regression statistics}

The results of the fixed effects regression analysis are presented in Table 2. The analysis with all countries shows that overall ALMP, and specific programmes, interact with EPL strictness and UB generosity. However, some of these interactions lose their significance during the sensitivity analysis. The interactions that are less robust are italicised in Table 2 and the results of the sensitivity analysis are presented in Table 3.

To test the hypotheses that either EPL positively $\left(\mathrm{H}_{1}\right)$ or negatively $\left(\mathrm{H}_{2}\right)$ moderates the relation between ALMPs and long-term unemployment, we estimated model 2, 4 and 5. Model 2 in Table 2 shows that both temporary and regular EPL negatively moderate the relation between ALMP in general and long-term unemployment. Both interactions are influenced by the composition of the sample but the direction of the regression coefficient remains the same when a single country is excluded from the sample. Thus, hypothesis $\mathrm{H}_{1}$ and $\mathrm{H}_{2}$ are rejected in the case of regular and temporary EPL in relation to overall ALMP effort. This implies that in general ALMPs are not complementary to EPL in relation to reducing long-term unemployment.

Concerning the specific programmes of ALMP, model 5 shows that temporary EPL negatively interacts with ALMP pes and ALMP training and does not interact with ALMP employment. The interaction between ALMP training and temporary EPL is no longer significant during the sensitivity analysis. However, the regression coefficient does not differ substantially and the significance levels only marginally cross the critical value. This implies a statistical power issue instead of the influence of an outlier. The interaction between ALMP pes and temporary EPL does not seem to be affected by the composition of the sample. The plots of the interaction effects are presented in Figure 2. The left panel in Figure 2 shows that when temporary EPL becomes stricter the negative effect of ALMP pes on long-term unemployment becomes stronger. With regard to the interaction between ALMP training and temporary EPL, the middle panel in Figure 2 shows that when temporary EPL becomes less strict the effect of ALMP training is positive but when temporary EPL strictness increases the relation between ALMP training and long-term unemployment is negative. Our results support hypothesis $\mathrm{H}_{2}$ in the case of temporary EPL with regard to ALMP pes and ALMP training and reject hypothesis H1. In the case of ALMP 

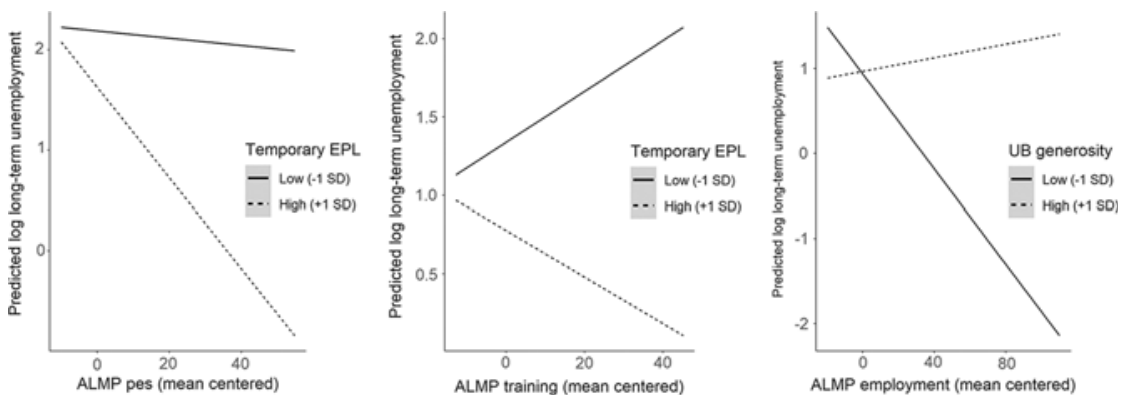

Figure 2. Plots of interactions

employment, both hypotheses $\mathrm{H}_{1}$ and $\mathrm{H}_{2}$ are rejected. This suggests that temporary EPL is complementary to ALMP pes and ALMP training when the level of strictness increases. However, ALMP training seems to form a discomplementarity with temporary EPL when the level of strictness decreases.

The results from model 4 also show that regular EPL negatively moderates the relation of ALMP pes and ALMP training with long-term unemployment, and positively moderates the relation between ALMP employment and longterm unemployment. However, all interactions lose their significance when a specific country is excluded from the analysis. Hypotheses $\mathrm{H}_{1}$ and $\mathrm{H}_{2}$ are therefore rejected in the case of regular EPL and specific ALMP programmes. As a result, our analysis indicates that specific ALMP programmes do not form complementarities with regular EPL in reducing long-term unemployment.

To test the hypotheses that either UB generosity positively $\left(\mathrm{H}_{3}\right)$ or negatively $\left(\mathrm{H}_{4}\right)$ moderates the relation between ALMPs and long-term unemployment, we estimated model 2 and 6 . The results from model 2 show that UBs positively moderate the relation between overall ALMP and long-term unemployment. This outcome is robust. With regard to the specific programmes, model 6 shows that the interaction (between UBs and ALMP employment) is the main driver of the positive interaction. The right panel in Figure 2 illustrates the interaction between UBs and ALMP employment and shows that when UB generosity becomes less generous the effect of ALMP employment becomes negative but when the level of UB generosity increases the effect becomes positive. The results support hypothesis $\mathrm{H}_{4}$ for overall ALMP and ALMP employment programmes, and reject hypothesis $\mathrm{H}_{3}$. Hence, UBs are complementary to ALMPs, and especially ALMP employment, in reducing long-term unemployment when UBs become less generous.

UB generosity also seems to negatively moderate the effect of ALMP pes and ALMP training on the long-term unemployment rate. However, the observed negative interaction between UBs and ALMP training is heavily influenced by Ireland because the coefficient changes its direction when Ireland is 
TABLE 2: Fixed effect linear regression on log long-term unemployment

\begin{tabular}{|c|c|c|c|c|c|c|}
\hline & Model 1 & Model 2 & Model 3 & Model 4 & Model 5 & Model 6 \\
\hline ALMP total & $\begin{array}{c}-0.007^{* * *} \\
(0.001)\end{array}$ & $\begin{array}{c}-0.010^{* * *} \\
(0.002)\end{array}$ & & & & \\
\hline ALMP pes & & & $\begin{array}{l}-0.010 \\
(0.006)\end{array}$ & $\begin{array}{c}-0.026^{* * *} \\
(0.007)\end{array}$ & $\begin{array}{l}-0.024^{* * *} \\
(0.007)\end{array}$ & $\begin{array}{c}-0.022^{* * *} \\
(0.006)\end{array}$ \\
\hline ALMP training & & & $\begin{array}{c}0.003 \\
(0.003)\end{array}$ & $\begin{array}{l}-0.000 \\
(0.003)\end{array}$ & $\begin{array}{l}0.001 \\
(0.003)\end{array}$ & $\begin{array}{l}0.010^{* *} \\
(0.004)\end{array}$ \\
\hline ALMP employment & & & $\begin{array}{c}-0.009^{* *} \\
(0.003)\end{array}$ & $\begin{array}{l}-0.002 \\
(0.004)\end{array}$ & $\begin{array}{l}-0.008^{*} \\
(0.003)\end{array}$ & $\begin{array}{c}-0.012^{\star *} \\
(0.004)\end{array}$ \\
\hline Regular EPL & $\begin{array}{l}-0.331 \\
(0.190)\end{array}$ & $\begin{array}{c}-0.433^{*} \\
(0.188)\end{array}$ & $\begin{array}{l}-0.123 \\
(0.203)\end{array}$ & $\begin{array}{l}-0.107 \\
(0.196)\end{array}$ & $\begin{array}{l}-0.226 \\
(0.192)\end{array}$ & $\begin{array}{l}-0.160 \\
(0.194)\end{array}$ \\
\hline Temporary EPL & $\begin{array}{l}-0.062 \\
(0.046)\end{array}$ & $\begin{array}{l}-0.114^{*} \\
(0.052)\end{array}$ & $\begin{array}{l}-0.079 \\
(0.046)\end{array}$ & $\begin{array}{l}-0.083 \\
(0.044)\end{array}$ & $\begin{array}{l}-0.277^{* * *} \\
(0.056)\end{array}$ & $\begin{array}{c}-0.090^{*} \\
(0.044)\end{array}$ \\
\hline UBs & $\begin{array}{l}1.806^{* *} \\
(0.545)\end{array}$ & $\begin{array}{l}1.756^{* *} \\
(0.551)\end{array}$ & $\begin{array}{l}1.535^{* *} \\
(0.553)\end{array}$ & $\begin{array}{l}1.112^{\star} \\
(0.559)\end{array}$ & $\begin{array}{l}1.163^{*} \\
(0.537)\end{array}$ & $\begin{array}{c}0.102 \\
(0.604)\end{array}$ \\
\hline Regular EPL ${ }^{\star} \mathrm{ALMP}$ total & & $\begin{array}{c}-0.007^{*} \\
(0.003)\end{array}$ & & & & \\
\hline Temporary EPL ALMP total & & $\begin{array}{c}-0.004^{*} \\
(0.001)\end{array}$ & & & & \\
\hline $\mathrm{UBs}^{\star} \mathrm{ALMP}$ total & & $\begin{array}{l}0.031^{* *} \\
(0.011)\end{array}$ & & & & \\
\hline
\end{tabular}


TABLE 2: Continued

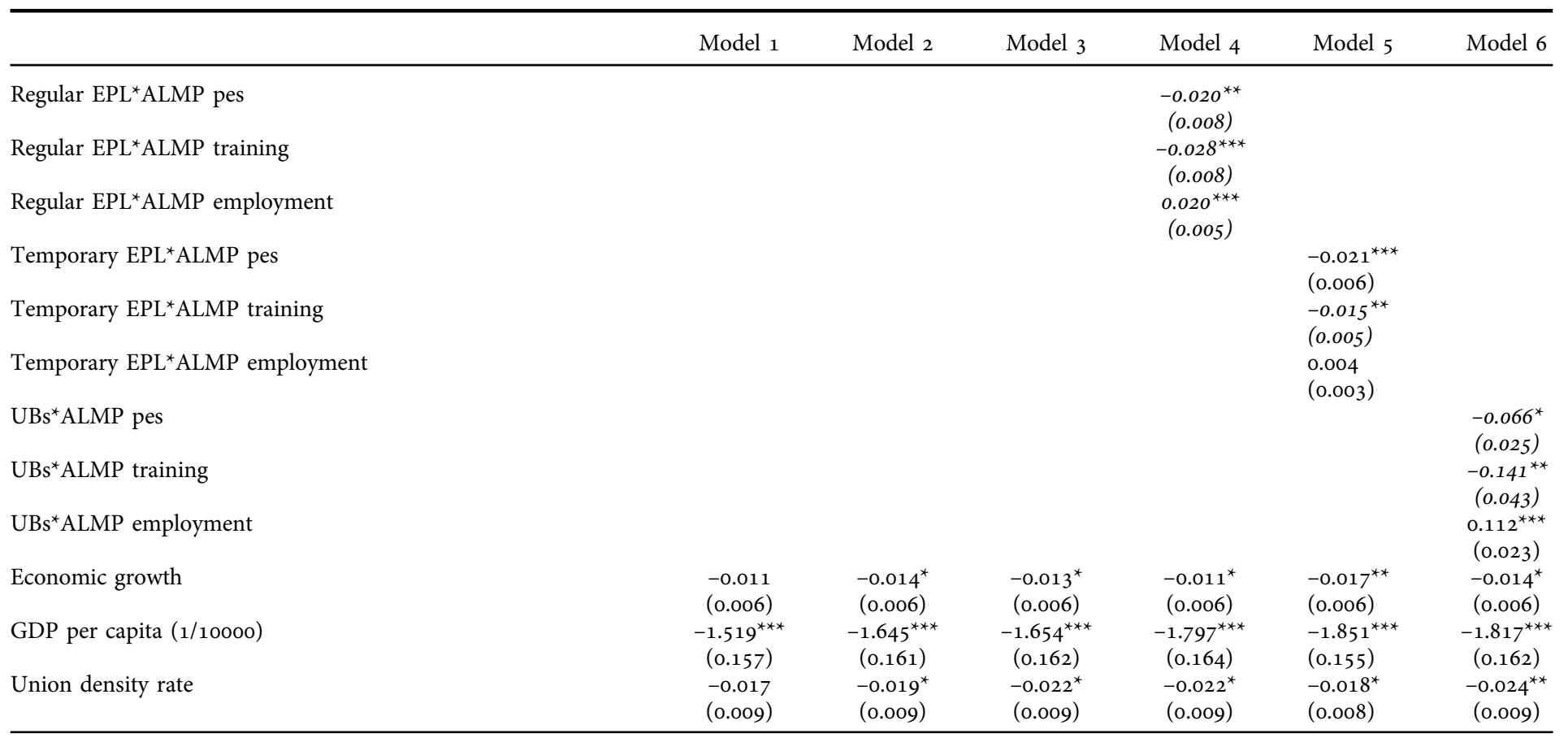


TABLE 2: Continued

\begin{tabular}{|c|c|c|c|c|c|c|}
\hline & Model 1 & Model 2 & Model 3 & Model 4 & Model 5 & Model 6 \\
\hline \multicolumn{7}{|c|}{ Coordination of wage setting (ref: fragmented wage bargaining) } \\
\hline Mixed industry and firm-level bargaining & $\begin{array}{l}-0.027 \\
(0.115)\end{array}$ & $\begin{array}{l}-0.070 \\
(0.112)\end{array}$ & $\begin{array}{l}-0.028 \\
(0.113)\end{array}$ & $\begin{array}{c}0.051 \\
(0.110)\end{array}$ & $\begin{array}{l}-0.065 \\
(0.106)\end{array}$ & $\begin{array}{c}0.013 \\
(0.108)\end{array}$ \\
\hline Negotiation guidelines based on centralized bargaining & $\begin{array}{l}-0.087 \\
(0.108)\end{array}$ & $\begin{array}{l}-0.156 \\
(0.107)\end{array}$ & $\begin{array}{l}-0.104 \\
(0.106)\end{array}$ & $\begin{array}{l}-0.110 \\
(0.103)\end{array}$ & $\begin{array}{l}-0.146 \\
(0.100)\end{array}$ & $\begin{array}{l}-0.110 \\
(0.101)\end{array}$ \\
\hline Wage norms based on centralized bargaining & $\begin{array}{c}-0.209 \\
(0.118)\end{array}$ & $\begin{array}{c}-0.298^{\star} \\
(0.118)\end{array}$ & $\begin{array}{c}-0.204 \\
(0.116)\end{array}$ & $\begin{array}{c}-0.146 \\
(0.114)\end{array}$ & $\begin{array}{l}-0.277^{*} \\
(0.110)\end{array}$ & $\begin{array}{c}-0.153 \\
(0.111)\end{array}$ \\
\hline \multirow[t]{2}{*}{$\begin{array}{l}\text { Maximum/minimum wage rates increases based on } \\
\text { centralized bargaining }\end{array}$} & -0.178 & $-0.285^{*}$ & -0.183 & -0.146 & -0.213 & -0.093 \\
\hline & $(0.121)$ & $(0.122)$ & $(0.119)$ & $(0.117)$ & $(0.114)$ & $(0.114)$ \\
\hline Old age dependency ratio & $\begin{array}{l}-0.071^{* * *} \\
(0.018)\end{array}$ & $\begin{array}{l}-0.080^{* * *} \\
(0.018)\end{array}$ & $\begin{array}{l}-0.089^{\star * *} \\
(0.019)\end{array}$ & $\begin{array}{l}-0.062^{* *} \\
(0.020)\end{array}$ & $\begin{array}{l}-0.115^{* * *} \\
(0.019)\end{array}$ & $\begin{array}{l}-0.083^{* * *} \\
(0.019)\end{array}$ \\
\hline Crude net migration rate & $\begin{array}{l}-0.029^{* * *} \\
(0.007)\end{array}$ & $\begin{array}{l}-0.024^{* * *} \\
(0.007)\end{array}$ & $\begin{array}{l}-0.027^{* * *} \\
(0.007)\end{array}$ & $\begin{aligned}-0.029^{* * *} & (0.006)\end{aligned}$ & $\begin{array}{l}-0.022^{* * *} \\
(0.007)\end{array}$ & $\begin{aligned}-0.030^{* * *} \\
(0.006)\end{aligned}$ \\
\hline Time & $\begin{array}{l}0.072^{* * *} \\
(0.009)\end{array}$ & $\begin{array}{l}0.077^{* * *} \\
(0.009)\end{array}$ & $\begin{array}{l}0.081^{* * *} \\
(0.009)\end{array}$ & $\begin{array}{l}0.086^{* * *} \\
(0.009)\end{array}$ & $\begin{array}{l}0.095^{* * *} \\
(0.009)\end{array}$ & $\begin{array}{c}0.089^{* * *} \\
(0.009)\end{array}$ \\
\hline $\mathrm{R}^{2}$ & 0.701 & 0.723 & 0.714 & 0743 & 0.755 & 0.746 \\
\hline Num. obs. & 239 & 239 & 239 & 239 & 239 & 239 \\
\hline
\end{tabular}

Note: ${ }^{\star *} \mathrm{p}<0.001,{ }^{\star *} \mathrm{p}<0.01,{ }^{\star} \mathrm{p}<0.05$; Italicised interaction coefficients are less robust, see Table 3 for more information. 
TABLE 3: Sensitivity analysis

\begin{tabular}{lll}
\hline Interaction & Country & $\begin{array}{c}\text { Regression coefficient if } \\
\text { country is excluded }\end{array}$ \\
\hline Regular EPL * overall ALMP & Portugal & $\mathrm{b}=-0.005, \mathrm{p}=0.166$ \\
Regular EPL * ALMP pes & Sweden & $\mathrm{b}=-0.011, \mathrm{p}=0.177$ \\
Regular EPL * ALMP training & Ireland & $\mathrm{b}=-0.010, \mathrm{p}=0.259$ \\
Regular EPL * ALMP employment & Netherlands & $\mathrm{b}=-0.010, \mathrm{p}=0.104$ \\
Temporary EPL * overall ALMP & Norway & $\mathrm{b}=-0.003, \mathrm{p}=0.142$ \\
& Spain & $\mathrm{b}=-0.002, \mathrm{p}=0.233$ \\
Temporary EPL * ALMP training & Ireland & $\mathrm{b}=-0.011, \mathrm{p}=0.062$ \\
& Spain & $\mathrm{b}=-0.010, \mathrm{p}=0.055$ \\
$\mathrm{UB}^{*}$ ALMP training & Ireland & $\mathrm{b}=0.028, \mathrm{p}=0.688$ \\
$\mathrm{UB} *$ ALMP pes & Portugal & $\mathrm{b}=-0.050, \mathrm{p}=0.055$ \\
& Sweden & $\mathrm{b}=-0.045, \mathrm{p}=0.091$ \\
& United Kingdom & $\mathrm{b}=-0.097, \mathrm{p}=0.146$ \\
\hline
\end{tabular}

excluded. When Portugal, Sweden or the United Kingdom is excluded from the sample, the observed negative interaction between UBs and ALMP pes is no longer significant. Both hypotheses $\mathrm{H}_{3}$ and $\mathrm{H}_{4}$ are rejected with regard to ALMP pes and ALMP training. This implies that ALMP pes and ALMP training are not complementary to UBs in lowering the long-term unemployment rate.

\section{Conclusion and discussion}

This study investigates how potential institutional complementarities influence the relationship between ALMP and long-term unemployment. More specifically, we investigated how and if EPL strictness and UB generosity moderate the relation between ALMPs and long-term unemployment. This enhances our insights into the observed effect heterogeneity of ALMPs that is reported in the literature on intended and unintended effects of ALMP.

The results show that ALMPs have differential effects on long-term unemployment depending on the institutional configuration of the labour market. Increased effort in public employment services and ALMP training programmes are associated with less long-term unemployment when temporary employment protection becomes stricter. One explanation is that strict temporary EPL decreases the likelihood of adverse selection processes. On average ALMP participants are less disadvantaged in such labour markets and therefore need fewer activation efforts (e.g. job search assistance or training) to successfully re-integrate into the labour market. Another explanation is that strict temporary EPL provides a necessary condition for ALMP participants to enjoy more employment stability when obtaining a new job. Employment stability increases the probability of sustainable reintegration into the labour market (Wulfgramm and Fervers, 2015) and therefore reduces the probability of future long-term 
unemployment. Furthermore, employment programmes seem to become more effective when UB generosity is decreased. This might be due to a reduction in the financial disincentive caused by UB generosity, which in turn reduces the possibility of a lock-in effect that follows from ALMP employment programme participation.

More generally, the observed complementarities might be based on two different institutional logics. The complementarity between more strict temporary EPL and ALMPs (like public employment services and training programmes) might be based on a logic emphasising durable labour relations, which lies at the heart of the coordinated market economy as identified in the Varieties of Capitalism (VoC) literature (Hall and Soskice, 2001). Norway provides an empirical example of this complementarity due to its strict temporary EPL. Duell et al. (2009) show that Norwegian activation measures lowered the unemployment rate. Dahl and Lorentzen (2005) also show that in Norway ALMP training programmes seem to increase the earnings of all participants, while employment programmes do not have an overall effect but have differential effects for various subgroups. This suggests that the complementarity between strict temporary EPL and ALMP measures is more focused on creating sustainable and durable labour relations in overall. Nevertheless, the logic of the complementary between less generous UBs and ALMP employment programmes might be based on a faster allocation of labour to adhere to the demand for flexible labour instead of forming durable labour relations, which fits within the central logic of the liberal market economy as described in the VoC (Hall and Soskice, 2001). As Wulfgramm and Fervers (2015) show, in countries with less generous UBs re-employment stability is reduced because of poor matchmaking resulting from economic hardship. Thus, even though the combination of decreased UB generosity and increased ALMP employment programme effort is associated with less long-term unemployment, it might also be associated with more re-employment instability. The United Kingdom might serve as an example because it has relatively less generous UBs and has shown activation successes in the past (Martin, 2015) but also shows an increase in involuntary temporary employment (Green and Livanos, 2015). Both examples of Norway and the United Kingdom suggest that complementarities involving ALMPs can reduce long-term unemployment but might differ in reintegration quality depending on the institutional configuration of the labour market. Hence, future research should focus on how specific institutional complementarities are related to the employment conditions and stability of former ALMP participants.

Furthermore, the observation that specific ALMPs are influenced by other institutions also indicates that the generalisability of micro-level studies on the efficacy of ALMP programmes is somewhat limited. Because these studies were conducted within a specific institutional setting, the observed effects might be 
the product of an interaction between the programme under study and other aspects of the institutional configuration. Researchers who perform micro-level studies on ALMPs should be aware of and reflect on the possibility that other institutions affect the workings of the programme under study. Knowledge produced in one institutional setting is not automatically transferable to another institutional setting, which implies that benchmarking should be performed with care. Additionally, policymakers should either select specific ALMP measures that fit within the institutional structure of the labour market or make adjustments in the institutional structure to improve the efficiency of ALMP programmes to reduce long-term unemployment.

\section{Limitations}

This study has several limitations. The measures used are very broad and may give a misrepresentation of the situation. For example, the EPL indicator of the OECD is a composite indicator and a low score in one domain can be compensated in another domain with a high score. As a result, the possibility exists that two countries that have a different EPL signature have the same score. Furthermore, we only looked at ALMP spending at the national level. Variations in within-country ALMP effort and practice are not measured as sectoral and municipal spending also varies. The spending variable also does not account for spending on ALMPs of the social partners. Thus, by only measuring national governmental spending the total effort is potentially under-estimated. Another limitation is that it is not known to whom the activation resources are primarily allocated and in what way. Thus, more detailed data is needed to further investigate how ALMPs affect long-term unemployment and in this way rule out the possibility of an ecological fallacy.

The estimated coefficients may also be biased due to reverse causality. It is plausible that long-term unemployment also explains some variance in the institutional configuration of a labour market. The current state of the labour market influences the decisions of policymakers and induces a positive correlation between long-term unemployment and labour market policies. Thus, this bicausality might lead to a biased estimation of the regression coefficient. However, Avdagic and Salardi (2013, p. 754) do not find clear empirical evidence for the hypothesis that causality runs from unemployment to labour market policies. This implies that this endogeneity problem is less problematic than one might initially think. Furthermore, this paper follows a linear line of reasoning and therefore utilises a linear analytical model to investigate the hypothesised complementarities. However, non-linear interactions are also a possibility (Hainmueller et al., 2019). Hence, future research should also explore and theorise potential non-linear complementarities as this fell outside of the scope of this study. Despite these limitations, we believe that this study provides useful 
and new insights in the study of labour market institutions and in particular ALMP.

\section{Supplementary Materials}

To view supplementary material for this article, please visit https://doi.org/10. $1017 /$ So047279419000515

\section{Acknowledgements}

The research leading to this publication has received funding from the EU's Seventh Framework Programme under grant agreement No. 320121 (Project INSPIRES).

\section{Notes}

1. This dataset can be found at: http://www.inspires-research.eu/

2. An online supplementary file contains the country specific means and standard deviations.

\section{References}

Allison, P. D. (2009), Fixed Effects Regression Models, Thousand Oaks: Sage Publications, Inc. Amable, B. (2016), 'Institutional complementarities in the dynamic comparative analysis of capitalism', Journal of Institutional Economics, 12(1), 79-103.

Avdagic, S. (2015), 'Does Deregulation Work? Reassessing the Unemployment Effects of Employment Protection', British Journal of Industrial Relations, 53(1), 6-26.

Avdagic, S. and Salardi, P. (2013), 'Tenuous link: Labour market institutions and unemployment in advanced and new market economies', Socio-Economic Review, 11(4), 739-769.

Becker, G. S. (1962), 'Investment in Human Capital: A Theoretical Analysis', Journal of Political Economy, 70(5), 9-49.

Bigos, M., Qaran, W., Fenger, M., Koster, F., Mascini, P. and van der Veen, R. (2013), D1.2 Codebook: European Labour Market Resilience (ELMaR) Dataset. Rotterdam.

Blanchard, O. J. (1991), 'Wage Bargaining and Unemployment Persistence', Journal of Money, Credit and Banking, 23(3), 277-292.

Blanchard, O. J. and Tirole, J. (2004), The Optimal Design of Employment Insurance and Employment Protection. A First Pass (NBER Working Paper Series No. 10443), Cambridge, MA.

Bonoli, G. (2005), 'The politics of the new social policies: Providing coverage against new social risks in mature welfare states', Policy and Politics, 33(3), 431-449.

Boone, J. and van Ours, J. C. (2004), Effective Active Labor Market Policies (IZA Discussion Paper Series No. 1335), Bonn.

Brown, A. J. G. and Koettl, J. (2015), 'Active labor market programs - employment gain or fiscal drain?', IZA Journal of Labor Economics, 4(12), 1-36.

Burtless, G. (1985), 'Are Targeted Wage Subsidies Harmful? Evidence from a Wage Voucher Experiment', ILR Review, 39(1), 105-114.

Calmfors, L., Forslund, A. and Hemström, M. (2001), 'Does active labour market policy work? Lessons from the Swedish experiences', Swedish Economic Policy Review, 85, 61-124.

Caminada, K., Goudswaard, K. and Koster, F. (2012), 'Social income transfers and poverty: A cross-country analysis for OECD countries', International Journal of Social Welfare, $21(2), 115-126$. 
Clasen, J., Clegg, D. and Goerne, A. (2016), 'Comparative Social Policy Analysis and Active Labour Market Policy: Putting Quality before Quantity', Journal of Social Policy, 45(1), $1-18$.

Crouch, C. and Keune, M. (2012), 'The Governance of Economic Uncertainty: Beyond the "New Social Risks" Analysis', in G. Bonoli and D. Natali (Eds.), The Politics of the New Welfare State (pp. 45-67), Oxford: Oxford University Press.

Dahl, E. and Lorentzen, T. (2005), 'What works for whom? An analysis of active labour market programmes in Norway',International Journal of Social Welfare, 14(2), 86-98.

de Beer, P. and Schils, T. (2009), The labour market triangle: Employment protection, unemployment compensation and activation in Europe. Cheltenham: Edward Elgar.

den Broeder, C. (1996), Institutions at work. Commitment and flexibility on the German and Dutch labour markets. Research Memorandum. The Hague: CPB Netherlands Bureau for Economic Policy Analysis.

Duell, N., Grubb, D. and Singh, S. (2009), Activation Policies in Norway (OECD Social, Employment and Migration Working Papers No. 78), Paris.

Eichhorst, W. and Konle-Seidl, R. (2006), The Interaction of Labor Market Regulation and Labor Market Policies in Welfare State Reform (IAB Discussion Paper No. 19), IAB Discussion Paper. Nürnberg.

Eriksson, B. S. and Rooth, D. (2014), 'Do Employers Use Unemployment as a Sorting Criterion When Hiring? Evidence from a Field Experiment', American Economic Review, 104(3), 1014-1039.

Eurostat. (2015), Unemployment rate. Retrieved from https:/ec.europa.eu/eurostat/cache/ metadata/en/une_esms.htm

Feldstein, M. and Poterba, J. (1984), 'Unemployment and Reservation Wages', Journal of Public Economics, 23, 141-167.

Gilbert, N. (2009), 'The Least Generous Welfare State? A Case of Blind Empiricism', Journal of Comparative Policy Analysis: Research and Practice, 11(3), 355-367.

Gordon, J. C. (2015), 'Protecting the unemployed: Varieties of unionism and the evolution of unemployment benefits and active labor market policy in the rich democracies', SocioEconomic Review, 13(1), 79-99.

Green, A. E. and Livanos, I. (2015), 'Involuntary Non-Standard Employment and the Economic Crisis: Regional Insights from the UK', Regional Studies, 49(7), 1223-1235.

Hall, P. A. and Soskice, D. (2001), Varieties of Capitalism: The Institutional Foundations of Comparative Advantage. Oxford: Oxford University Press.

Hainmueller, J., Mummolo, J. and Xu, Y (2019), 'How Much Should We Trust Estimates from Multiplicative Interaction Models? Simple Tools to Improve Empirical Practice', Political Analysis, 27(2) 163-192.

Hemerijck, A. (2012), 'Two or three waves of welfare state transformation?', in N. Morel, B. Palier, and J. Palme (Eds.), Towards a social investment state? Ideas, Policies and Challenges. (pp. 33-60), Bristol: The Policy Press.

Ingold, J. and Stuart, M. (2015), 'The Demand-Side of Active Labour Market Policies: A Regional Study of Employer Engagement in the Work Programme', Journal of Social Policy, 44(3), 1-20.

Krueger, A. B. and Mueller, A. (2010), 'Job search and unemployment insurance: New evidence from time use data', Journal of Public Economics, 94(3-4), 298-307.

Madsen, P. K. (2004), 'The Danish model of "flexicurity": experiences and lessons', Transfer: European Review of Labour and Research, 10(2), 187-207.

Martin, C. J. (2004), 'Reinventing Welfare Regimes: Employers and the Implementation of Active Social Policy', World Politics, 57(1), 39-69.

Martin, C. J. and Swank, D. (2004), 'Does the Organization of Capital Matter? Employers and Active Labor Market Policy at the National and Firm Levels', American Political Science Review, 98(4), 593-611.

Martin, J. P. (2015), 'Activation and active labour market policies in OECD countries: stylised facts and evidence on their effectiveness', IZA Journal of Labor Policy, 4(4), 1-29. 
Martin, J. P. and Grubb, D. (2001), 'What Works and for Whom: A Review of OECD Countries' Experiences with Active Labour Market Policies', Swedish Economic Policy Review, 8(14), 9-56.

Morel, N., Palier, B. and Palme, J. (2012), Towards a Social Investment State? Ideas Policies and Challenges. Bristol: The Policy Press.

OECD. (2015a), Gross domestic product (GDP) (indicator), https://doi.org/10.1787/dc2f 7aec-en

OECD. (2015b), OECD Indicators of Employment Protection. Retrieved from http://www. oecd.org/employment/emp/oecdindicatorsofemploymentprotection.htm

Pedersen, P. J. and Smith, N. (2002), 'Unemployment Traps: Do Financial Disincentives Matter?', European Sociological Review, 18(3), 271-288.

Scott, W. R. (2014), Institutions and Organizations. Thousand Oaks: Sage Publications, Inc.

Scruggs, L., Detlef, J. and Kati, K. (2014), Comparative Welfare Entitlements Dataset 2. Version 2014-03.

Sippola, M. (2013), 'The Awkward Choices Facing the Baltic Worker: Exit or Loyalty', Journal of Baltic Studies, 44(4), 451-473.

Swank, D. and Martin, C. J. (2001), 'Employers and the welfare state: The political economic organization of firms and social policy in contemporary capitalist democracies', Comparative Political Studies, 34(8), 889-923.

Taylor, P. E. and Walker, A. (1994), 'The Ageing Workforce Employers' Attitudes Towards Older People', Work, Employment \& Society, 8(4), 569-591.

Van Kersbergen, K. and Hemerijck, A. (2012), 'Two Decades of Change in Europe: The Emergence of the Social Investment State', Journal of Social Policy, 41(3), 475-492.

van Ours, J. C. (2004), 'The locking-in effect of subsidized jobs', Journal of Comparative Economics, 32(1), 37-55.

Wulfgramm, M. and Fervers, L. (2015), 'Unemployment and subsequent employment stability: Does labour market policy matter?', Socio-Economic Review, 13(4), 791-812. 